\title{
Distribution of benthic phototrophs, sulfate reducers, and methanogens in two adjacent saltern evaporation ponds in Eilat, Israel
}

\author{
Ketil Sørensen ${ }^{1, *}$, Klára Řeháková2,3, Eliška Zapomělová ${ }^{2}$, Aharon Oren ${ }^{4}$ \\ ${ }^{1}$ Department of Chemistry and Water Technology, Danish Technological Institute, Kongsvang Alle 29, \\ 8000 Aarhus C, Denmark \\ ${ }^{2}$ Biology Centre of ASCR, Institute of Hydrobiology, Na Sádkách 7, České Budějovice 370 05, Czech Republic \\ ${ }^{3}$ Institute of Botany, ASCR, Dukelská 135, Třeboň 379 82, Czech Republic \\ ${ }^{4}$ Department of Plant and Environmental Sciences, The Institute of Life Sciences, and the Moshe Shilo Minerva Center \\ for Marine Biogeochemistry, The Hebrew University of Jerusalem, Jerusalem, Israel
}

\begin{abstract}
The vertical distribution of phototrophic and non-phototrophic microorganisms was examined in 2 saltern evaporation ponds with salinities of 156 and $206 \mathrm{~g} \mathrm{l}^{-1}$. The biogeochemistry of these 2 ponds was examined using microsensors for oxygen, $\mathrm{pH}$ and sulfide. These measurements showed that net rates of oxygen production/consumption were significantly higher at a salinity of 156 than at $206 \mathrm{~g} \mathrm{l}^{-1}$. The distribution of phototrophic microorganisms was studied by microscopy, which revealed several differences between the 2 crusts. The relative amounts of Bacteria, Archaea, sulfate reducers and methanogens were studied by real-time quantitative PCR amplification of genes for $16 \mathrm{~S}$ rRNA, dissimilatory sulfite reductase (DSR), and methyl coenzyme $M$ reductase (MCR). Sulfate reducers and methanogens were detected only in the deepest part of the phototrophic zone and below. Sulfate reducers were most abundant in the zone just below the phototrophic layer, where the DSR gene copy number was $\sim 1.5 \%$ that of the $16 \mathrm{~S}$ rRNA gene copy number. Methanogens were much less abundant than sulfate reducers, and the number of MCR gene copies never exceeded $0.1 \%$ of the number of $16 \mathrm{~S}$ rRNA gene copies. Methanogens were less abundant at a salinity of 206 than at $156 \mathrm{~g} \mathrm{l}^{-1}$. Inter-pond and vertical variations in the composition of methanogenic and sulfate reducing communities were further characterized by DGGE analysis. The detected sulfate reducers were affiliated with 4 different phylogenetic groups that included members of the Desulfovibrionales, relatives of Desulfotomaculum, and 2 deeply branching groups with no close cultured relatives. The detected phylotypes were distributed in a distinct pattern in the crust according to both biogeochemical regimes and salinity. Methanogens were all affiliated with the known halophilic genera Methanohalophilus and Methanohalobium.
\end{abstract}

KEY WORDS: Salterns $\cdot$ Phototrophs $\cdot$ Sulfate reducers $\cdot$ Methanogens $\cdot$ Molecular ecology

\section{INTRODUCTION}

Solar salterns are systems in which microbial communities develop at salinities ranging from that of seawater to that at halite saturation (e.g. Canfield \& Des Marais 1993, Caumette et al. 1994, Ionescu et al. 2007, Oren 2009, this Special Issue). In these systems, salts are precipitated in a series of evaporation ponds according to their different solubilities, thus forming a crystalline crust of carbonates, gypsum $\left(\mathrm{CaSO}_{4}\right.$. $2 \mathrm{H}_{2} \mathrm{O}$ ), and/or halite depending on the specific salinity. Solar salterns are thus excellent model systems for studies of biogeochemical cycles and microbiology at different salinities. At salinities roughly between 150 and $250 \mathrm{~g} \mathrm{l}^{-1}$, gypsum is the main precipitation product of marine salterns and thick gypsum crusts are formed on the bottom of the ponds. Phototrophic algae and cyanobacteria colonize these crusts, form- 
ing endoevaporitic, oxygenic communities that extend several centimeters below the crust-water interface (Caumette et al. 1994, Oren et al. 1995, Oren 2005). The upper oxygenic zone is usually divided into at least 3 different layers: an upper orange or brown layer, a deep bright green layer, and a white layer without any phototrophs in-between (Oren et al. 1995). Below the oxygenic zone, one or more layers of anoxygenic phototrophs are present. Previous measurement of light penetration in the crust showed that photoactive light is available throughout these zones (Oren et al. 1995). Further into the sediment, the crust turns dark grey and sulfidic. The biogeochemistry, structure, and composition of such endoevaporitic microbial communities developing at a salinity of $\sim 200 \mathrm{~g} \mathrm{l}^{-1}$ have previously been studied in Eilat (Oren et al. 2009). From16S rRNA studies as well as biogeochemical measurements, it has been known that sulfate reducing as well as methanogenic microorganisms are present in the crusts. It has also been shown that, while the methanogens appear to be well adapted to in situ salinities, the sulfate reducers are highly salt stressed (Sørensen et al. 2004). The different groups of oxygenic and anoxygenic phototrophs also appear to be inhibited to some degree by the high salinity (Canfield et al. 2004, Sørensen et al. 2004). As a result, the short-term metabolic response of the crust microbial community changes dramatically when exposed to different salinities between 100 and $200 \mathrm{~g} \mathrm{l}^{-1}$.

At first glance, the gypsum crusts that develop in ponds of different salinities appear to be very similar, irrespective of the salinity. However, given the strong effect of salinity on rates of primary production and the progressive exclusion of functional groups with increased salinity due to energy limitations (Oren 1999, 2001), significant differences may exist between the microbial communities. The present study was undertaken in order to compare the communities of phototrophs, methanogens, and sulfate reducers in 2 adjacent ponds with salinities of 156 and $206 \mathrm{~g} \mathrm{l}^{-1}$, respectively, in the saltern system in Eilat. The biogeochemistry of different layers in the 2 crusts was studied, and the microbial communities of phototrophs, sulfate reducers, and methanogens were characterized by microscopy and molecular analysis.

\section{MATERIALS AND METHODS}

Field site and sampling. Samples of the gypsum crust covering the bottom of 2 ponds were collected. The water depth was $\sim 10 \mathrm{~cm}$ and the salinities at the time of sampling were 156 and $206 \mathrm{~g} \mathrm{l}^{-1}$ in Ponds 103 and 200, respectively. The exact salinities in the 2 ponds vary over time depending on the management of the ponds, but are always higher in Pond 200 because it is situated downstream of Pond 103. Previous studies of Pond 200 have measured salinities similar to that reported here (Canfield et al. 2004, Sørensen et al. 2004, Oren et al. 2005).

Microscopic analysis. A light microscope (Olympus BX51) with a digital camera (Olympus DP 70) was used for the identification and documentation of species. Subsamples for diatom identification were prepared following methods described by Beneš et al. (2002) and mounted into an artificial resin (Von Stosch 1974). Frustules were observed using the Olympus BX51 light microscope with differential interference contrast (DIC) and a scanning electron microscope (SEM JEOL 6380). Sample preparation for SEM followed the protocol of Nebesářová (2002). Diatom taxa were identified according to Hustedt (1930, 1959), Krammer (2000), Krammer \& Lange-Bertalot (1985, 1986, 1988, 1991a,b), Lange-Bertalot (2001), Noël (1982), and Fourtanier \& Kociolek (2007). Relationships between species composition and locality or single layer affiliations were visualized by principal component analyses (PCA), for which the relative scale of species abundance was used. Statistical analyses were performed using the program CANOCO (Ter Braak \& Šmilauer 1998) and ordination diagrams were created using CanoDraw software (Šmilauer 1992).

Microsensor profiling. Large pieces of crust $(\sim 20 \times$ $20 \times 10 \mathrm{~cm}$ ) were loosened using a chisel and a hammer, transferred to an aquarium, and transported to the laboratory while covered in brine. The aquaria were placed at ambient temperature outside the laboratory, where the crust experienced a light regime identical to that in the ponds. The outside of the aquaria was constantly cooled by flowing seawater with a temperature of $22^{\circ} \mathrm{C}$. Inside the aquarium, the crusts were supported by sand in order to preserve their shape during measurements and to prevent light from entering from the sides. In general, samples were retrieved from the salterns in the morning and mounted in aquaria before noon. Oxygen, sulfide, and $\mathrm{pH}$ profiles in the crusts were measured the following day using Clark-type microsensors with guard cathodes (Revsbech 1989) that were calibrated and employed according to the manufacturer's instructions (Unisense). Detection limits for oxygen and sulfide were $\sim 50 \mathrm{nM}$. Each electrode was inserted in a hypodermic needle $5 \mathrm{~cm}$ long and $0.8 \mathrm{~mm}$ thick (outer diameter) (Canfield et al. 2004). These sensors were sufficiently sturdy to penetrate the crust without breaking during measurements, and were controlled using a micromanipulator and a computer-controlled motor unit. Data collected from the picoammeter were continuously recorded using Sensor Trace PRO v1.9 software (Unisense). 
Sample preparation and DNA extraction. Intact crust samples were collected during the morning and brought to the laboratory. Individual layers were identified based on color and separated using forceps and a spatula. The thickness of each of the layers varied significantly, with the upper cyanobacteria-rich layers being $<1$ to several centimeters thick and the layers below being somewhat thinner. At least $2 \mathrm{~g}$ of each layer were retrieved from a collection of crust pieces (at least 5), placed in a $15 \mathrm{ml}$ sterile plastic tube, and covered by 4 volumes of DNA Later (Qiagen). Samples were kept frozen until further analysis. Prior to DNA extraction, samples were thawed, homogenized with a spatula, and briefly vortexed. Approximately $1 \mathrm{~g}$ of each sample was used for DNA extraction using the Qiagen soil extraction kit.

Quantification of 16S rRNA, MCR, and DSR genes. Primers for bacterial and archaeal 16S rRNA, dissimilatory sulfite reductase (DSR), and methyl coenzyme $\mathrm{M}$ reductase (MCR) genes were employed in triplicate quantitative real-time PCR (Table 1). Standard curves were obtained using plasmids with a known insert of the respective gene. For bacterial and archaeal 16S rRNA, the inserts were full-length 16S rRNA genes from Escherichia coli and Archaeoglobus fulgidus. The MCR standard was a full-length gene from Methanobacterium sp. and the DSR gene was from Desulfovibrio sp. The reaction mix contained Brilliant qPCR SYBR Green master mix, $4 \mu \mathrm{M}$ of each primer, $0.1 \mu \mathrm{g} \mathrm{ll}^{-1}$ of BSA, and ROX as a reference dye (Stratagene). Reactions took place in a real-time thermocycler (MX 3005P) connected to a computer with software supplied by the manufacturer (Stratagene). An initial step at $94^{\circ} \mathrm{C}$ for 10 min was followed by 40 PCR cycles of $30 \mathrm{~s}$ at $94^{\circ} \mathrm{C}, 30 \mathrm{~s}$ at $56^{\circ} \mathrm{C}, 30 \mathrm{~s}$ at $72^{\circ} \mathrm{C}$, and a data acquisition step at $80^{\circ} \mathrm{C}$. Melting curves $\left(55\right.$ to $95^{\circ} \mathrm{C}$ ) were measured, and the specificity of the reactions was further evaluated by agarose gel electrophoresis $(2 \%)$ of the qPCR product.

Molecular fingerprinting. DGGE was performed to compare the prokaryotic communities containing genes for MCR (mcrA) and DSR ( $d s r \mathrm{~B})$ in the different samples. A nested PCR approach was used to ensure a high specificity of the reactions and good quality of the PCR products loaded on the gels. The mcrA genes were initially amplified in 30 PCR cycles (temperature and duration of each step as explained above) using the primer set ME1F and ME2R (Table 1) and a thermocycler (Gstorm, Stratagene). The products were diluted $10 \times$ and $1 \mu \mathrm{l}$ of the dilution was used in a 30-cycle nested PCR using primers ME2R and ME3F. The latter was supplied with a GC-tail at the $5^{\prime}$ end (5'-CGC CCG CCG CGC GCG GCG GGC GGG GCG GGG GCA CGG GGG G$\left.3^{\prime}\right)$. A similar approach was used for DGGE analysis of the $d s r \mathrm{~B}$ gene. Primers dsr1F and dsr4R were employed in an initial amplification of $d s r \mathrm{~B}$ genes, and primers dsrP2060F and dsr4R were employed to amplify a part of the $d s r \mathrm{~B}$ gene in the nested PCR. In this case, primer dsrP2060F was supplied with the GC-tail.

A Dcode Universal Mutation Detection system was used for the DGGE analysis (Biorad). Stock solutions of $8 \%$ acrylamide:Bis-acrylamide (37.5:1) with 0 and $100 \%$ denaturant were mixed according to the manufacturer's instructions. The PCR products were loaded on DGGE gels with a 30 to $70 \%$ denaturing gradient and run at $60^{\circ} \mathrm{C}$ and $130 \mathrm{~V}$ for $10 \mathrm{~h}$. The gels were visualized on a transillumination table equipped with an imaging system (Universal HOOD II, Biorad) and connected to a PC with software for picture capture and analysis (Biorad). Bands were excised and vortexed for $30 \mathrm{~s}$ in $200 \mu \mathrm{l}$ PCR-grade water. After an overnight incubation at $4^{\circ} \mathrm{C}, 2 \mu \mathrm{l}$ of the water phase was transferred to PCR reaction tubes and reamplified with the respective primer set. The products were sequenced commercially (DNA Technology).

Obtained sequences were aligned with related sequences from the National Center for Biotechnology Information (NCBI) database in Bioedit using the CLUSTAL $\mathrm{W}$ function. This alignment was manually edited and used for generating phylogenetic trees in PHYLIP 4.0. For each alignment, a distance matrix was calculated using Jukes-Cantor, and a distance tree was constructed using neighbor joining. Bootstrapping was performed with 1000 replicate samplings. The sequences retrieved in the present study are accessible

Table 1. List of primers used in this study

\begin{tabular}{|llll|}
\hline Gene & Primer & Sequence & Source \\
\hline Bacterial 16S rRNA & BAC341F & CCT ACG GGR GGC AGC AG CCG TCA ATT CGA GTT T & Muyzer et al. (1993) \\
& UNIV907R & & Muyzer et al. (1995) \\
Archaeal 16S rRNA & ARC344F & AYG GGG YGC ASC AGG SG & Muyzer et al. (1993) \\
& ARC915R & GTG CTC CCC CAT TCC T & Hendrik \& Muyzer (2001) \\
dsrAB & P2060F & CAA CAT CGT YCA YAC CCA GGG & Geets et al. (2006) \\
& Dsr4R & GTG TAG CAG TTA CCG CA & Wagner et al. (1998) \\
mcrA & ME1F & GCM ATG CAR ATH GGW ATG TC & Hales et al. (1996) \\
& ME2R & TCA TBG CRT AGT TDG GRT AGT & Nunoura et al. (2008) \\
\hline
\end{tabular}


in GenBank (www.ncbi.nlm.nih.gov/) under accession numbers FJ866763 to FJ866780.

\section{RESULTS}

\section{Biogeochemical measurements}

Microsensor measurements were performed in several different locations 2 to $5 \mathrm{~cm}$ apart on the crust surface. Examples of oxygen and sulfide profiles measured in the crust are shown in Figs. 1 \& 2. Profiles were measured in the dark before sunrise $(5: 30 \mathrm{~h})$ to determine whether sulfide accumulated during the night, and throughout the day to monitor the net dynamics of oxygen in the system. During a daily cycle, the temperature varied from $21^{\circ} \mathrm{C}$ in the early morning to $25^{\circ} \mathrm{C}$ in the afternoon. As noted by Sørensen et al. (2005), there was a high degree of spatial heterogeneity in the crust, and the exact depth of each of the layers varied significantly. The distribution of the different layers of the crust within which measurements took place is indicated in Figs. 1 \& 2. Oxygen accumulated in the upper few centimeters of both crusts during the day and was exhausted during the night. The crust from Pond 103 reached much higher oxygen concentrations, and formation and escape of bubbles (presumably oxygen) from the surface was

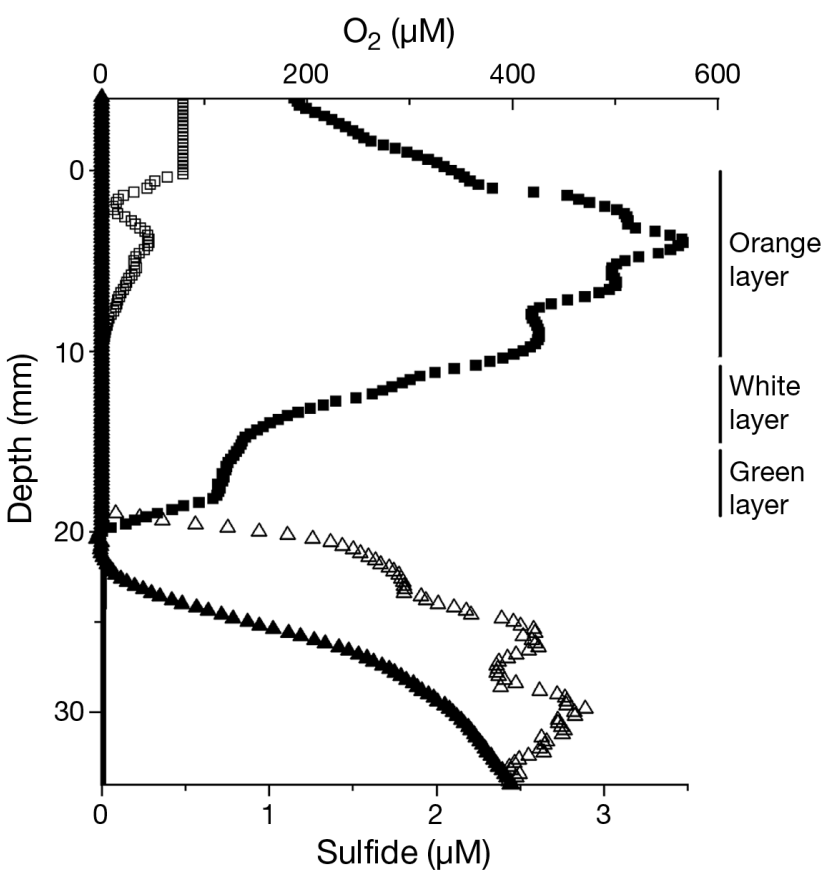

Fig. 1. Profiles of oxygen $(\square, \square)$ and sulfide $(\boldsymbol{\Delta}, \Delta)$ measured in Pond 103 in the dark before sunrise at 5:30 $\mathrm{h}$ (open symbols) and at 10:00 h (black symbols). Positions of the orange, white, and green layers are indicated

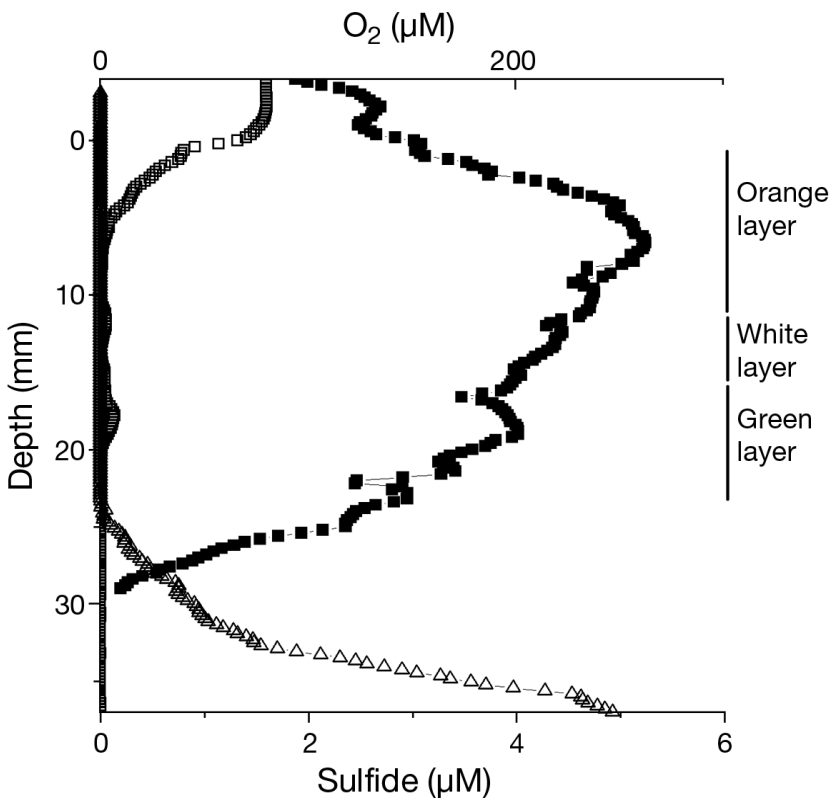

Fig. 2. Profiles of oxygen $(\square, \square)$ and sulfide $(\boldsymbol{\Delta}, \Delta)$ measured in Pond 200 in the dark before sunrise at 5:30 h (open symbols) and at 11:30 h (black symbols). Sulfide was not detected at 11:30 h. Positions of the orange, white, and green layers are indicated

much more pronounced than in the crust from Pond 200 (Woelfel et al. 2009, this Special Issue). Interestingly, a small peak of residual oxygen remained in the crust at approximately 1-2 $\mathrm{cm}$ depth throughout the night. This small pool of residual oxygen was consistently observed in the morning in all profiles for both ponds. Further details concerning the oxygen measurements are given elsewhere (Woelfel et al. 2009). Sulfide was observed below the phototrophic zone. During the day, when oxygen accumulated in the surface layers, sulfide was removed from the upper part of the anoxygenic zone. No sulfide was observed during the day in Pond 200. Most of the oxygen generated during the day is retained and respired within the crust (Canfield et al. 2004, Woelfel et al. 2009).

\section{Microscopic analysis}

The results presented here refer to morphologies (cell shapes, colony formation) of the bacteria found in different sediment layers, without any information on their taxonomic affiliations or physiologies. Nevertheless, the results demonstrate that bacterial communities in the different sediment layers were considerably diversified even based on mere morphology.

The layers in Pond 103 were divided into 3 different groups based on PCA (Fig. 3a). The first group was represented by 2 upper orange and white layers 
(0-1 cm deep). They were characterized mainly by the presence of colonial and single-celled cyanobacteria (Halothece sp., Halospirulina tapeticola type 1, Leptolyngbya cf. woronichinii, and Phormidium sp.). Halochromatium/ Marichromatium-like cells (oval bacterial cells of pink color) and spiral bacteria were also recognized in these layers. The green and pink layers at $1-2$ and 2-3 cm depth formed another group. These were colonized mainly by cyanobacteria including cf. Leptolyngbya, Phormidium cf. inundatum, an unidentified nostocacean cyanobacterium, the diatom Nitzschia aff. N. lorenziana, and unclassified colorless rod-like bacteria. The olive-green layer $(3-4.5 \mathrm{~cm})$ formed the third group, which was characterized by cyanobacteria (Aphanocapsa sp., Pseudanabaena sp., and Phormidium laetevirens) together with the diatoms Amphora coffeaeformis and Nitzschia aff. N. acula.

The result of the PCA analysis of the microscopy data from Pond 200 is shown in Fig. 3b. The order of the layers is indicated by numbers (from 1: uppermost to 10: bottommost) as the layers were very thin and exact depths therefore impossible to measure. The orange, white and green layers (layers 1 to 3) were colonized mainly by the cyanobacteria Halothece sp., Leptolyngbya cf. woronichinii and Phormidium laetevirens. The deeper olive-green and purple layers 4 and 5 contained the cyanobacteria Halospirulina tapeticola type 1, Halospirulina tapeticola type 2, cf. Leptolyngbya, Phormidium cf. inundatum, and Phormidium sp. The deeper crust layers of Pond 200, presumably below the phototrophic zone, also contained both cyanobacteria and other phototrophs (especially layers 7 and 8). As indicated by its position near the centre of the PCA diagram, layer 6 represented a transition between the surface layers (1 to 5) and the deeper layers characterized in the present study. Layer 7 was colonized mainly by the single-celled cyanobacterium Halothece sp. and oval bacterial cells of pink color (Halochromatium/ Marichromatium-like cells). Layers 8 and 9 represented a transition between layer
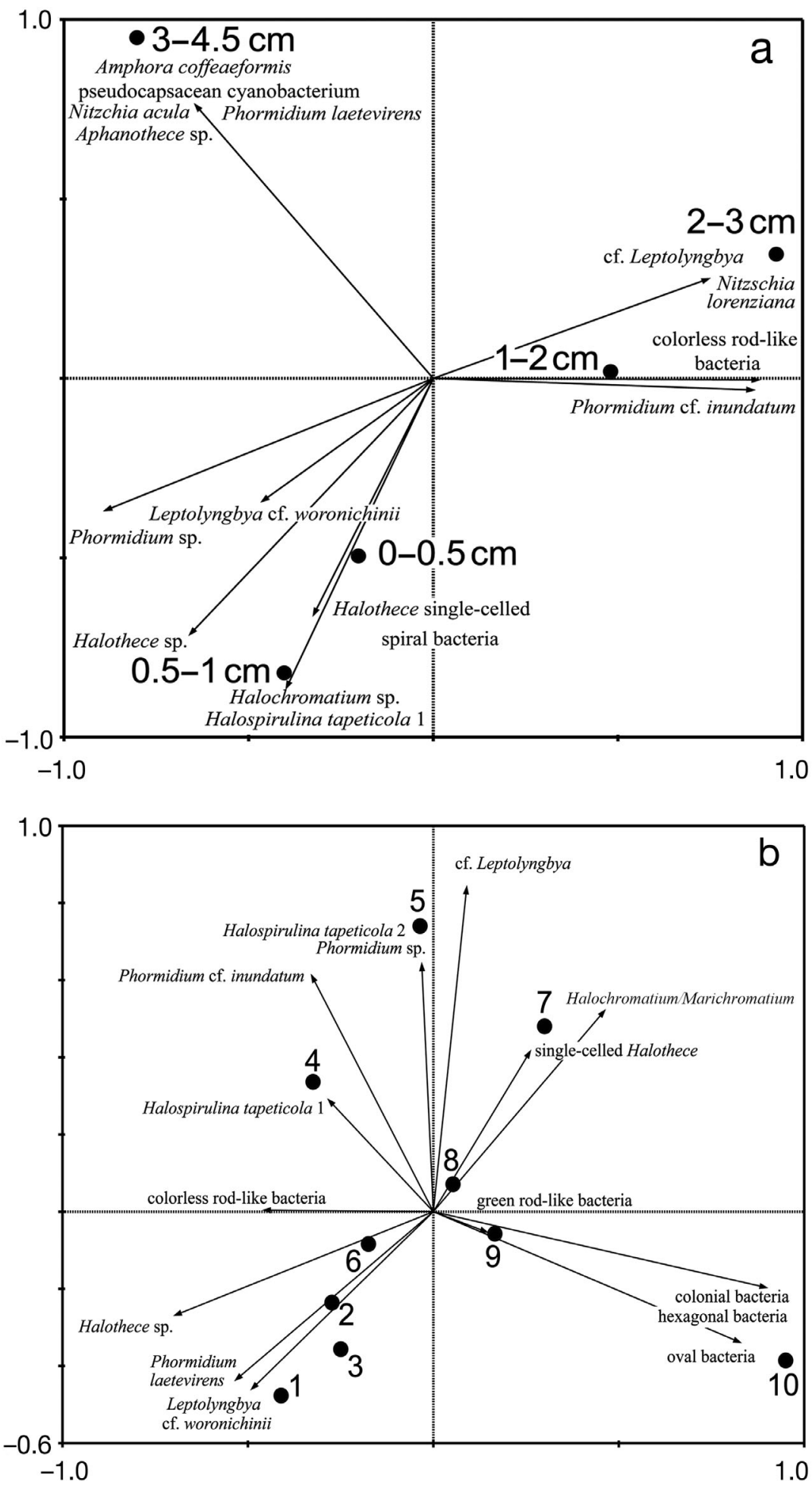

Fig. 3. Principal component analyses (PCA) of species composition of benthic communities in the different sediment layers of Ponds 103 (a) and 200 (b). The first and second canonical axes together explain 76.4 and $47.1 \%$ of the total variability, respectively. (๑) Sediment layers; depths are either indicated (a), or annotated in numerical order (b), with 1 being the uppermost and 10 being the bottommost layer. Exact depths of the layers in Pond 200 were impossible to measure because they were very thin 


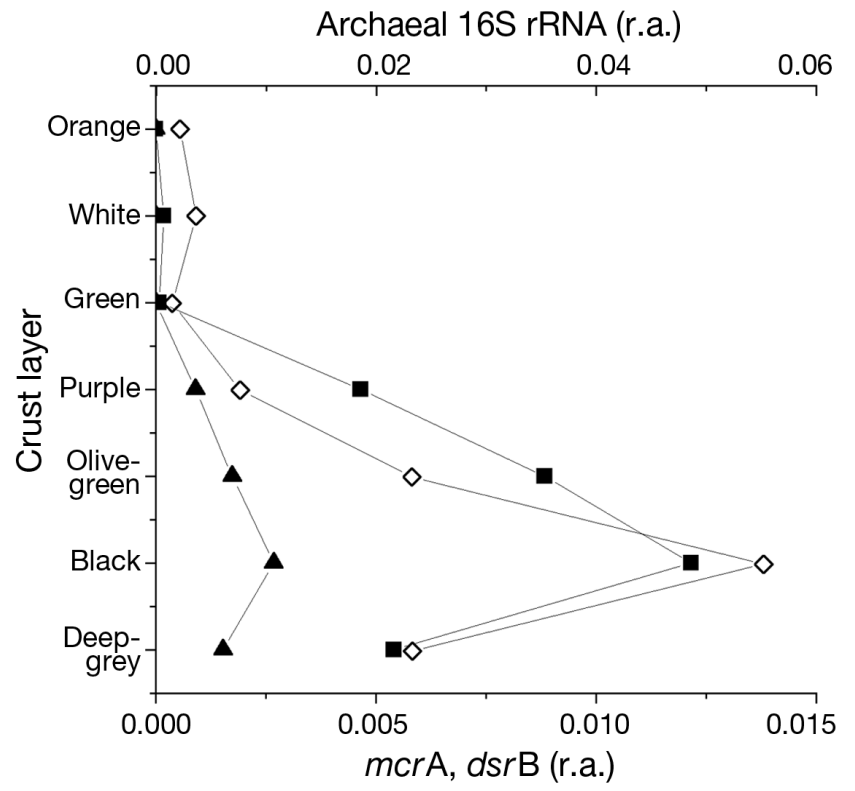

Fig. 4. Abundance of archaeal 16S rRNA $(\diamond)$, mcrA $(\boldsymbol{\Delta})$, and $d s r \mathrm{~B}(\boldsymbol{\square})$ genes within the different layers of crust from Pond 103. Units are relative abundances (r.a.) compared to bacterial 16S rRNA genes

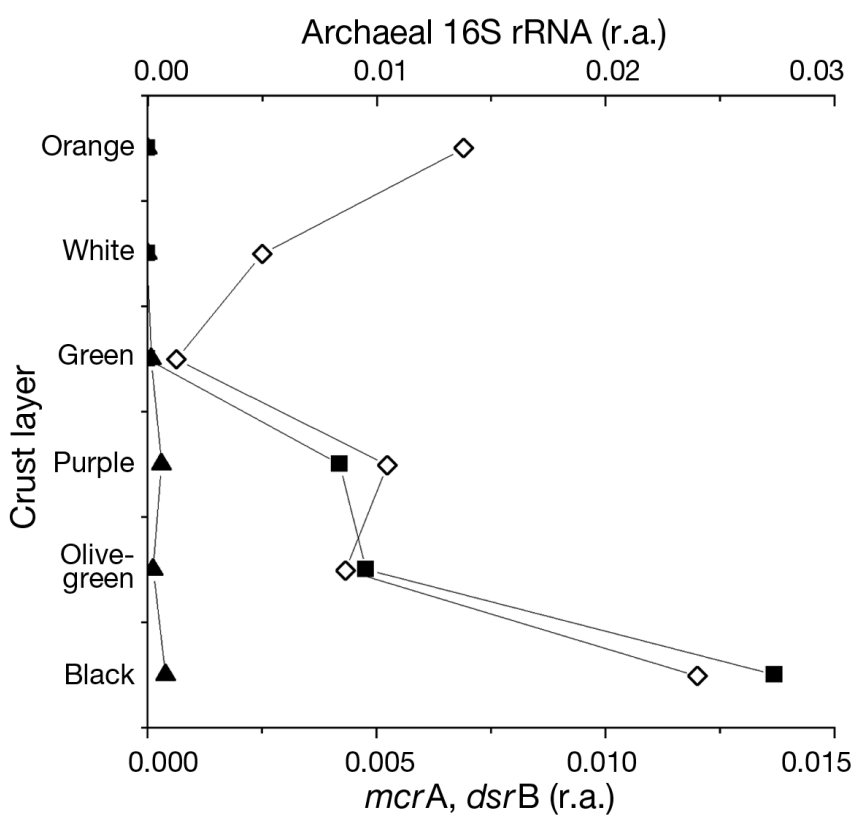

Fig. 5. Abundance of archaeal 16S rRNA $(\diamond), \operatorname{mcrA}(\mathbf{\Delta})$, and $d s r \mathrm{~B}(\mathbf{\square})$ genes within the different layers of crust from Pond 200. Units are relative abundances (r.a.) compared to bacterial 16S rRNA genes

7 and the bottommost layer 10, as indicated by their position near the centre of the diagram. Layer 10 contained no cyanobacteria or other obvious phototrophs. Cells in this layer were single-celled oval, green rod-like, or colonial coccoid.

\section{Quantification of ribosomal and functional genes}

The relative amounts of genes for archaeal and bacterial 16s rRNA, MCR and DSR in each layer of the 2 crusts are summarized in Figs. 4 \& 5. In both ponds, methanogens were detected only in trace amounts in layers above the purple zone. Below this, the total number of archaeal 16S rRNA genes far exceeded that of the MCR gene. The highest relative numbers of MCR genes were obtained in the dark, sulfidic layer just below the olive-green layer in both Pond 103 $(0.27 \%)$ and Pond $200(0.04 \%)$. Throughout the profile, the numbers were significantly lower in Pond 200 than in Pond 103. As was the case with the mcrA gene, $d s r \mathrm{~B}$ was mainly present in the layers below the green layer. Similar numbers were obtained from the 2 crusts, with the highest abundance $(1.2 \%$ of bacterial $16 \mathrm{~S}$ rRNA gene counts) being observed in the layer below the olive-green layer.

\section{Comparison of sulfate reducers and methanogens}

DGGE analysis revealed changes in the $d s r$ B-containing communities both between the ponds and with depth in the crust (Fig. 6). Several of the visualized bands were sequenced as indicated in Fig. 7 to determine the phylogenetic affiliation of the corresponding organisms. The sequences were affiliated with 4 different operational taxonomic units (OTUs; Fig. 7). Two of these (OTU 1 and 2) were deeply branching and had

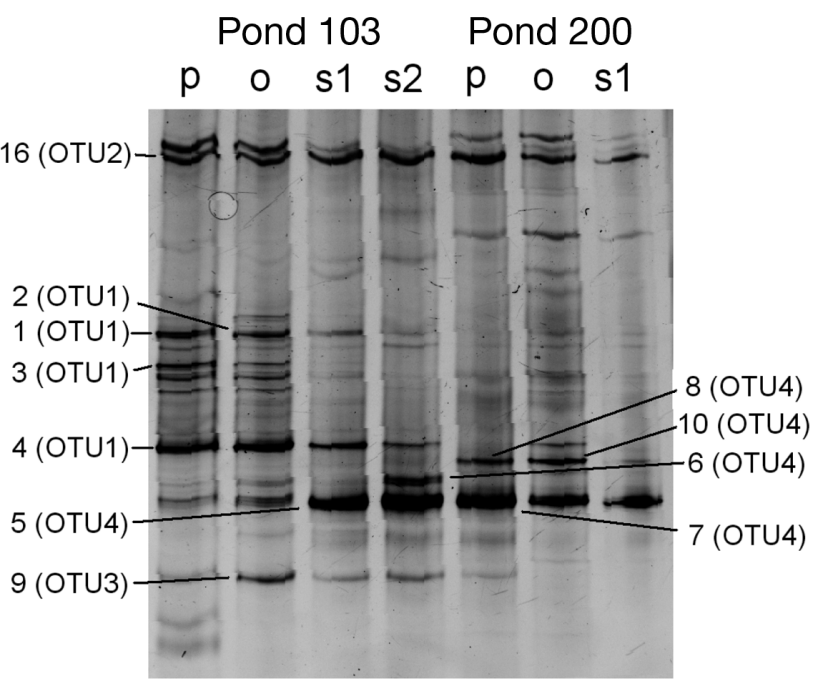

Fig. 6. DGGE gel with amplified dissimilatory sulfite reductase (DSR) genes from 7 crust samples from Ponds 103 and 200. Bands were numbered (1 to 10 and 16), sequenced and identified as indicated. p: purple layer, o: olive-colored layer; s1: sulfidic layer below the olive-colored layer; s2: deeper sulfidic layer $\sim 2 \mathrm{~cm}$ below the olive-colored layer, OTU: operational taxonomic unit 


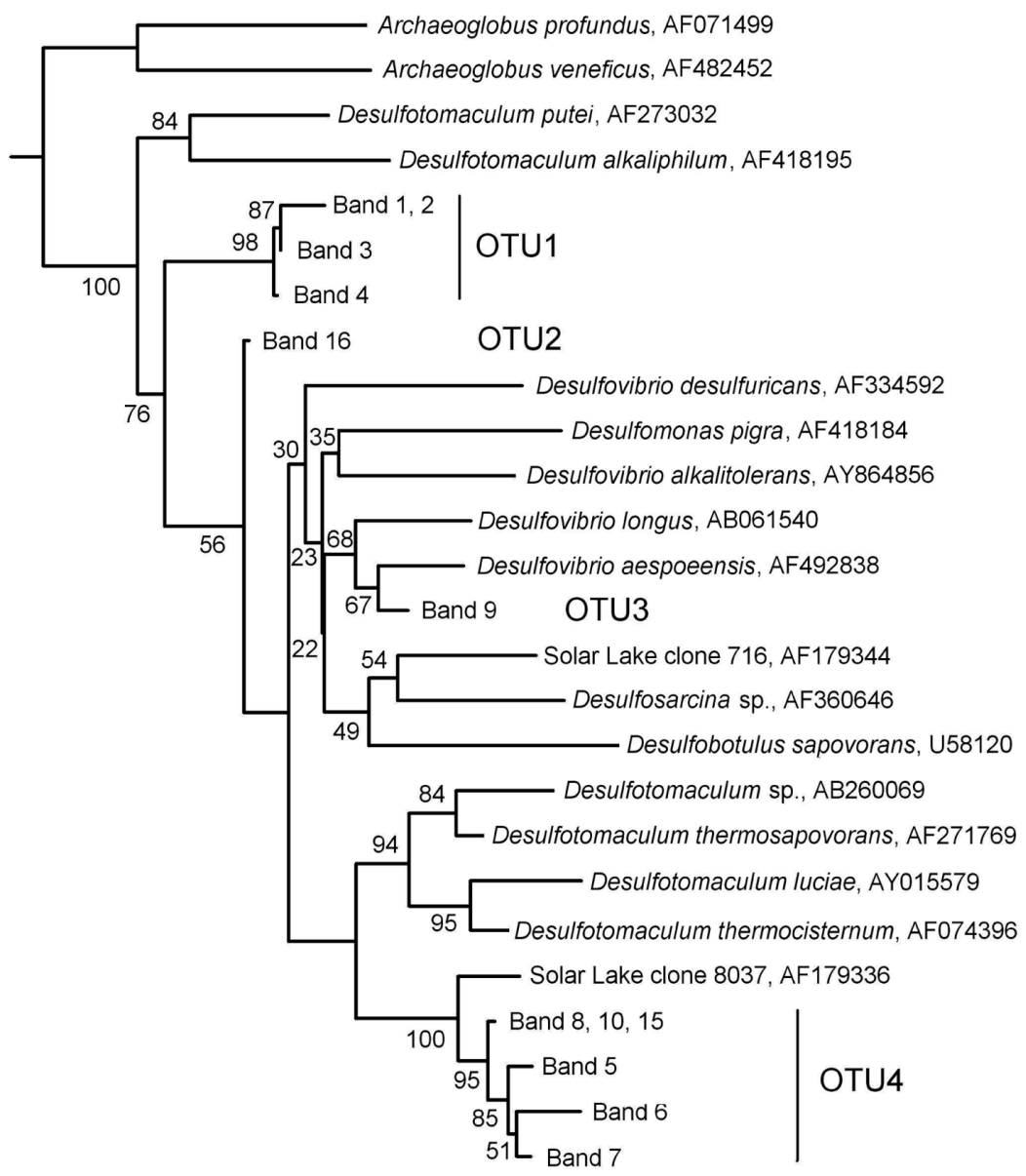

Fig. 7. Neighbor-joining tree of dissimilatory sulfite reductase (DSR) sequences recovered from the different crust samples (see Fig. 6) and related sequences. Bootstrap values (1000 replications) are indicated at each node. OTU: operational taxonomic unit

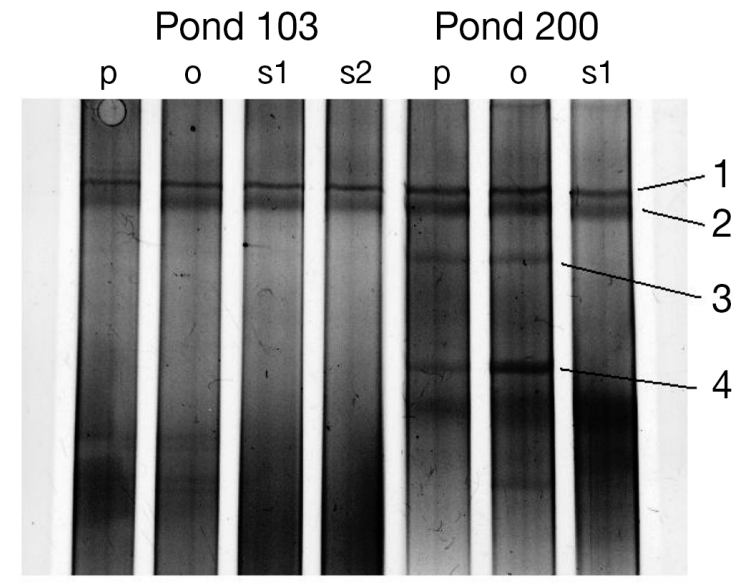

Fig. 8. DGGE gel with methyl coenzyme M reductase (MCR) genes from 7 different crust samples from Ponds 103 and 200. Bands 1 to 4 were excised and sequenced. p: purple layer, o: olive-colored layer; s1: sulfidic layer below the olive-colored layer; s2: deeper sulfidic layer $\sim 2 \mathrm{~cm}$ below the olive-colored layer (1 to 4 ) no close relatives in the database. One OTU (OTU 3; Fig. 7) was affiliated with the Desulfovibrionales, and another was closely related with the gram-positive genus Desulfotomaculum (OTU 4). In Pond 103, the DSR banding patterns were similar in the purple and the olivegreen layers. Similar bands were also recovered from the deeper sulfidic layers, but the relative intensities of the bands were different. The dominating bands in samples from the purple and the olivegreen layers were all affiliated with OTU 1. The band affiliated with OTU 3 was present throughout the profile and was most prominent in the olive-green layer. Several bands affiliated with OTU 4 were dominant in the deeper layers of the anoxic zone of this crust. Less variation with depth was observed in Pond 200. In this pond, 2 OTU 4-affiliated bands were identified, one of which was also present in Pond 103. Several weak bands that were not successfully sequenced appeared to represent organisms that were also found in the Pond 103 crust. The band affiliated with OTU 3 was not present in Pond 200, while the band representing OTU 2 was present with similar intensities in all samples from both ponds regardless of depth.

McrA genes were also analyzed by DGGE, and 4 bands were excised and sequenced (Fig. 8). Two strong bands present in all samples (labeled 1 and 2 in Fig. 8) were identified as members of the genus Methanohalophilus. Two other bands were affiliated with the genera Methanohalophilus or Methanohalobium (bands 3 and 4 in Fig. 8). All identified methanogens are thus affiliated with known halophilic genera of the order Methanosarcinales.

\section{DISCUSSION}

\section{Oxygen and sulfide dynamics}

Photosynthetic rates were not measured in the present study, but the much higher accumulation of oxygen in the crust from Pond 103 than in the crust from Pond 200 clearly indicates that the net rates of photosynthesis were higher at the lower salinity. This confirms previous findings on the impact of salinity on the cyanobacteria in the system (Canfield et al. 2004, Sørensen et al. 2004). Oxygen was rapidly respired in 
the oxygenic layers when photosynthesis ceased in the evening.

Dissolved sulfide was not observed during the night in the orange, white, and green surface layers of either of the 2 crusts. In previous studies, sulfate reduction was observed within the upper layers of crust from Pond 200 (Canfield et al. 2004, Sørensen et al. 2004). Biological re-oxidation of sulfide and/or precipitation of sulfide with metal ions may efficiently remove sulfide from the water phase even in the presence of sulfate reduction. Thus, the absence of free sulfide in pore water as observed here does not exclude the presence of sulfate reduction. In general, the oxygen and sulfide profiles did not overlap. This may indicate that electron acceptors other than oxygen (e.g. nitrate) were employed by sulfide oxidizing prokaryotes in the 2 crusts.

The bottom layers of the crust are likely to be disturbed during sampling and transportation, both due to physical disturbance and porewater drainage. Although care was taken to minimize such effects during sampling, we cannot rule out the possibility that in situ sulfate reduction rates may have been higher than in the crust samples, and that sulfide may accumulate to higher concentrations in situ. Disturbance and porewater drainage are less likely to have affected the sulfate reducers in the upper phototrophic zone where large amounts of mucus excreted by bacteria stabilized the crust structure.

\section{Photosynthetic communities}

Results from the microscopic analyses showed clear differences not only with depth in the crust, but also between analogous layers from Ponds 103 and 200 (Fig. 3a,b). Studies of crust from Pond 200 have previously demonstrated that light penetrates several centimeters into the crust (Oren et al. 1995), and that the changing quantity and quality of incident light in different layers are both affected by and shape the community of phototrophs at different depths. Differences in photosynthetic community structure among single sediment layers and various ponds were also found by Prášil et al. (2009, this Special Issue) by means of emission spectroscopy and kinetic fluorometry.

Our findings are in good agreement with previous reports of carotenoid-rich orange-colored cyanobacteria of the Halothece-Aphanothece group as being typical inhabitants of upper sediment layers of ponds with higher salinities (157 to $303 \mathrm{~g} \mathrm{l}^{-1}$ ). Underneath, a darkgreen layer of cyanobacteria of the genus Phormidium is usually observed (Clavero et al. 1994). On the other hand, the layers colonized by cyanobacteria and algae were surprisingly thick in Eilat (up to $5 \mathrm{~cm}$ ) compared with the depths of only several millimeters reported from other parts of the world (Jonkers et al. 2003)

\section{Non-photosynthetic communities}

Bacteria were much more abundant than Archaea in all layers of the crust. The surface peak in archaeal abundance in Pond 200 is probably caused by sedimentation of halobacteria from the overlying brine and/or by growth of halobacteria within the oxic layers of the crust itself (Sørensen et al. 2005). Members of the Halobacteriales are generally found in environments with salt concentrations exceeding 150 to $200 \mathrm{~g}$ $\mathrm{I}^{-1}$, which is consistent with a larger population in Pond 200 where salinity was higher (Oren 2006). The total number of Archaea far exceeded the number of methanogens at all depths of the crust and at both salinities. This is consistent with previous observations from the crust in Pond 200, where clone library construction of archaeal 16S rRNA yielded mainly sequences affiliated with the Halobacteriales as well as several uncultured groups that were not related to known methanogens (Sørensen et al. 2005).

In general, the diversity of methanogens appeared to be limited, since only members of the genera Methanohalobium and Methanohalophilus were detected. The diversity of methanogens appeared to be lowest in Pond 103, where only Methanohalophilus spp. were detected. Methanohalophilus spp. were also detected in crust from Pond 200 during an earlier cloning study (Sørensen et al. 2005). Members of both genera are known to grow at salinities similar to those in Pond 103 and 200, and to utilize non-competitive substrates such as methylamine and trimethylamine for methanogenesis. Previous studies showed that the methanogens in Pond 200 were well adapted to the high salinity, and that the impact of sulfate reduction on rates of methanogenesis was less pronounced at salinities approaching 200 (Sørensen et al. 2004). These observations are consistent with the apparently higher diversity of methanogens in Pond 200 compared to Pond 103.

The dsrB-containing community varied both with depth in the crust and with salinity. Samples for DNA extraction were collected and dissected during the day when the surface layers were rich in dissolved oxygen. Previous reports from microbial mats have shown that anaerobic sulfate reducers are able to migrate up to $2 \mathrm{~mm}$ over a diel cycle in response to changing photosynthetic activity (e.g. Fourçans et al. 2008). However, each of the layers in the mats studied here were several $\mathrm{mm}$ to $\mathrm{cm}$ thick, and it is not known whether migration over such long distances occurs. Two of the 4 OTUs of $d s r B$ genes were affiliated with known sulfate 
reducing groups. The remaining 2 had no close relatives in culture and may represent either sulfate reducers or sulfide oxidizers.

The qPCR approach showed that the proportion of $d s r \mathrm{~B}$ to $16 \mathrm{~S}$ rRNA increased below the oxygenic zone, probably reflecting an increased relative abundance of sulfate reducers. Sulfide did not accumulate within the oxygenic zone of the crust during the night, even in layers where oxygen was entirely depleted, but this does not necessarily rule out the presence of sulfate reduction as noted above. However, the fact that $d s r \mathrm{~B}$ genes remained below detection limit suggests that sulfate reducers and sulfide oxidizers constitute a small minority of the prokaryotic population in these layers. Other studies of microbial mats from hypersaline systems such as Solar Lake (Sinai, Egypt) have revealed large numbers of sulfate reducing organisms within the oxygenic zone (Minz et al. 1999).

\section{Structure of endolithic microbial mats at high salinity}

A diverse and spatially highly structured community of photo- and heterotrophic prokaryotes was observed at both salinities. Although the appearances of the mats from both ponds with salinities of 156 and $206 \mathrm{~g}$ $\mathrm{l}^{-1}$ are quite similar, there are important differences in both the phototrophic and heterotrophic communities. The detailed structure of the phototrophic communities in each layer differed between crusts from the 2 ponds. This is probably caused by complex interactions among salinity effects on productivity, patterns of light penetration, and nutrient status in each of the layers over the diel cycle. Sulfate reducing communities varied with depth in the crust, and their diversity appeared to be lower in the high salinity pond. Although the number of methanogens relative to the total number of bacteria was smaller at the high salinity, the diversity was as high, and possibly even higher, than in the lower salinity pond.

Acknowledgements. We thank the Batsheva de Rothschild Foundation, Bar Ilan University, the Moshe Shilo Center for Marine Biogeochemistry, and the staff of the Interuniversity Institute for funding and logistic support. We also thank the Israel Salt Company in Eilat, Israel for allowing access to the salterns. The Grant Agency of the Czech Republic project no. 206/06/0462, GA AS CR KJB 600960703, and Program Support of Targeted Research in the Academy of Sciences of CR projects no. 1Q600170504 and AV0Z60050516 provided financial assistance for this study. This study was performed during the 8th International Workshop of the Group for Aquatic Primary Productivity (GAP) and the Batsheva de Rothschild Seminar on Gross and Net Primary Productivity held at the Interuniversity Institute for Marine Sciences, Eilat, Israel in April 2008.

\section{LITERATURE CITED}

Beneš J, Kaštovský J, Kočárová R, Kočár P, Kubečková K, Pokorný P, Starec P (2002) Archaeobotany of the Old Prague Town defence system, Czech Republic: archaeology, macro-remains, pollen, and diatoms. Veg Hist Archaeobot 11:107-119

Canfield DE, Des Marais DJ (1993) Biogeochemical cycles of carbon, sulfur, and free oxygen in a microbial mat. Geochim Cosmochim Acta 57:3971-3984

> Canfield DE, Sørensen K, Oren A (2004) Biogeochemistry of a gypsum-encrusted microbial ecosystem. Geobiology 2: 133-150

> Caumette P, Matheron R, Raymond N, Relexans JC (1994) Microbial mats in the hypersaline ponds of Mediterranean salterns (Salins-de-Giraud, France). FEMS Microbiol Ecol 13:273-286

Clavero E, Grimalt JO, Merino V, Hernández-Mariné M (1994) Structure of the sediment at depositional saline environments. In: Stal LJ, Caumette P (eds) Microbial mats. Structure, development and environmental significance. Springer-Verlag, Berlin, p 91-96

> Fourçans A, Ranchou-Peyruse A, Caumette P, Duran R (2008) Molecular analysis of the spatio-temporal distribution of sulfate-reducing bacteria (SRB) in Camargue (France) hypersaline microbial mat. Microb Ecol 56:90-100

Fourtanier E, Kociolek JP (2007) Catalogue of diatom names. California Academy of Sciences, on-line version. www.calacademy.org/research/diatoms/names/index.asp. Accessed November 2008

Geets J, Borreman B, Diels L, Springael D, Vangronsveld J, van der Lelie D, Vanbroekhoeven K (2006) DsrB genebased DGGE for community and diversity surveys of sulfate-reducing bacteria. J Microbiol Methods 66:194-205

Hales BA, Edwards C, Ritchie DA, Hall G, Pickup RW, Saunders JR (1996) Isolation and identification of methanogenspecific DNA from blanket bog peat by PCR amplification and sequence analysis. Appl Environ Microbiol 62:668-675

Hendrik S, Muyzer G (2001) Denaturing gradient gel electrophoresis in marine microbial ecology. In: Paul JH (ed) Methods in microbiology: marine microbiology. Academic Press, San Francisco, CA, p 425-468

Hustedt F (1930) Die Süsswasserflora Deutschlands, Österreichs und der Schweiz, 10. Bacillariales (Diatomeae). Gustav Fischer, Jena

Hustedt F (1959) Die Kieselalgen Deutschlands, Österreichs und der Schweiz mit Berücksichtigung der übrigen Länder Europas sowie der angrenzenden Meeresgebiete. In: Rabenhorst L (1927) Kryptogamen-Flora von Deutschland, Österreich und der Schweiz. Band VII, Teil 2. Akademische Verlagsgesellschaft Geest und Portig K.-G., Leipzig

> Ionescu D, Lipski A, Altendorf K, Oren A (2007) Characterization of the endoevaporitic microbial communities in a hypersaline gypsum crust by fatty acid analysis. Hydrobiologia 576:15-26

Jonkers MJ, Ludwig R, De Wit R, Pringault $\mathrm{O}$ and others (2003) Structural and functional analysis of a microbial mat ecosystem from a unique permanent hypersaline inland lake: La Salada de Chiprana (NE Spain). FEMS Microbiol Ecol 44:175-189

Krammer K (2000) Diatoms of Europe, Vol 1. The genus Pinnularia. A.R.G. Gantner Verlag, Ruggell

Krammer K, Lange-Bertalot H (1985) Naviculaceae. Neue und wenig bekannte Taxa, neue Kombinationen und Synonyme sowie Bemerkungen zu einigen Gattungen. Bibliotheca Diatomologica, Band 9. J. Cramer Verlag, BerlinStuttgart 
Krammer K, Lange-Bertalot H (1986) Bacillariophyceae, 1. Teil Naviculaceae. In: Ettl H, Gerloff J, Heynig H, Mollenhauer D (eds) Süsswasserflora von Mitteleuropa 2/1. Gustav Fischer Verlag, Stuttgart

Krammer K, Lange-Bertalot H (1988) Bacillariophyceae, 2. Teil Bacillariaceae, Epithemiaceae, Surirellaceae. In: Ettl H, Gerloff J, Heynig H, Mollenhauer D (eds) Süsswasserflora von Mitteleuropa 2/2. Gustav Fischer Verlag, Stuttgart

Krammer K, Lange-Bertalot H (1991a) Bacillariophyceae, 3. Teil Centrales, Fragilariaceae, Eunotiaceae. In: Ettl $\mathrm{H}$, Gerloff J, Heynig H, Mollenhauer D (eds) Süsswasserflora von Mitteleuropa 2/3. Gustav Fischer Verlag, Stuttgart

Krammer K, Lange-Bertalot H (1991b) Bacillariophyceae, 4. Teil Achnanthaceae, Kritische Ergänzungen zu Navicula (Lineolate) und Gomphonema. In: Ettl H, Gerloff J, Heynig H, Mollenhauer D (eds) Süsswasserflora von Mitteleuropa 2/4. Gustav Fischer Verlag, Stuttgart

Lange-Bertalot H (2001) Diatoms of Europe, Vol 2. Navicula sensu stricto, 10 genera separated from Navicula sensu lato, Frustulia. A.R.G. Gantner Verlag, Ruggell

> Minz D, Fishbain S, Green SJ, Muyzer G, Cohen Y, Rittmann BE, Stahl DA (1999) Unexpected population distribution in a microbial mat community: sulfate-reducing bacteria localized to the highly oxic chemocline in contrast to a eukaryotic preference for anoxia. Appl Environ Microbiol 65:4659-4665

Muyzer G, Dewaal EC, Uitterlinden AG (1993) Profiling of complex microbial populations by denaturing gradient gel electrophoresis analysis of polymerase chain reactionamplified genes coding for $16 \mathrm{~S}$ ribosomal RNA. Appl Environ Microbiol 59:695-700

> Muyzer G, Teske A, Wirsen CO, Jannasch HW (1995) Phylogenetic relationships of Thiomicrospira species and their identification in deep-sea hydrothermal vent samples by denaturing gradient gel electrophoresis of $16 \mathrm{~S}$ rDNA fragments. Arch Microbiol 164:165-172

Nebesáŕová J (2002) Elektronová mikroskopie pro biology. Multimediální uãební texty. Available at: www.paru.cas. cz/lem/book/index.html

Noël D (1982) Les diatomees des saumures des marais salants de Salin-de-Giraud (Sud de la France). Geol Mediterr IX:413-446

Nunoura T, Oida H, Miyazaki J, Miyashita A, Imachi H, Takai K (2008) Quantification of mcrA by fluorescent PCR in methanogenic and methanotrophic microbial communities. FEMS Microbiol Ecol 64:240-247

Oren A (1999) Bioenergetic aspects of halophilism. Microbiol Mol Biol Rev 63:334-348

Oren A (2001) The bioenergetic basis for the decrease in metabolic diversity in increasing salt concentrations: implications for the functioning of salt lake ecosystems. Hydrobiologia 466:61-72

Oren A (2005) Microscopic examination of microbial communities along a salinity gradient in saltern evaporation ponds: a 'halophilic safari'. In: Gunde-Cimerman N, Oren

Editorial responsibility: Ilana Berman-Frank,

Ramat Gan, Israel
A, Plemenitaš A (eds) Adaptation to life at high salt concentrations in Archaea, Bacteria, and Eukarya. Springer, Dordrecht, p 41-57

Oren A (2006) Life at high salt concentrations. In: Dworkin M, Falkow S, Rosenberg E, Schleifer K-H, Stackebrandt E (eds) The prokaryotes. A handbook on the biology of bacteria: ecophysiology and biochemistry, Vol 2. Springer, New York, p 263-282

Oren A (2009) Saltern evaporation ponds as model systems for the study of primary production processes under hypersaline conditions. Aquat Microb Ecol 56:193-204

> Oren A, Kühl M, Karsten U (1995) An endoevaporitic microbial mat within a gypsum crust: zonation of phototrophs, photopigments, and light penetration. Mar Ecol Prog Ser 128:151-159

Oren A, Ionescu D, Lipski A, Altendorf K (2005) Fatty acid analysis of a layered community of cyanobacteria developing in a hypersaline gypsum crust. Algological Studies 117:339-347

> Oren A, Sørensen KB, Canfield DE, Teske AP, Ionescu D, Lipski A, Altendorf K (2009) Microbial communities and processes within a hypersaline gypsum crust in a saltern evaporation pond (Eilat, Israel). Hydrobiologia 626:15-26

Prášil O, Bína D, Medová H, Řeháková K, Zapomělová E, Veselá J, Oren A (2009) Emission spectroscopy and kinetic fluorometry studies of phototrophic microbial communities along a salinity gradient in solar saltern evaporation ponds of Eilat, Israel. Aquat Microb Ecol 56:285-296

Revsbech NP (1989) An oxygen microsensor with a guard cathode. Limnol Oceanogr 34:474-478

Šmilauer P (1992) CanoDraw users guide v. 3.0. Microcomputer Power, Ithaca, NY

Sørensen KB, Canfield DE, Oren A (2004) Salt responses of benthic microbial communities in a solar saltern (Eilat, Israel). Appl Environ Microbiol 70:1608-1616

Sørensen KB, Canfield DE, Teske AP, Oren A (2005) Community composition of a hypersaline endoevaporitic microbial mat. Appl Environ Microbiol 71:7352-7365

Ter Braak CJF, Šmilauer P (1998) CANOCO reference manual. Microcomputer Power, Ithaca, NY

Von Stosch H-A (1974) Pleurax, seine Synthese und seine Verwendung zur Einbettung und Darstellung der Zellwände von Diatomeen, Peridineen und anderen Algen, sowie für eine neue Methode zur Elektivfärbung von Dinoflagellaten-Panzern. Arch Protist 116:132-141

Wagner M, Roger AJ, Flax JL, Brusseau GA, Stahl DA (1998) Phylogeny of dissimilatory sulfite reductases supports an early origin of sulfate respiration. J Bacteriol 180: 2975-2982

Woelfel J, Sørensen K, Warkentin M, Forster S, Oren A, Schumann R (2009) Oxygen evolution in a hypersaline crust: in situ photosynthesis quantification by microelectrode profiling and use of planar optode spots in incubation chambers. Aquat Microb Ecol 56:263-273

Submitted: December 1, 2008; Accepted: April 6, 2009 Proofs received from author(s): June 20, 2009 